University of Nebraska - Lincoln

DigitalCommons@University of Nebraska - Lincoln

$12-1-1997$

\title{
A Not-so-distant Mirror: the 17th Amendment and Congressional Change
}

John R. Hibbing

University of Nebraska-Lincoln, jhibbing1@unl.edu

Sara Brandes Crook

Follow this and additional works at: https://digitalcommons.unl.edu/poliscifacpub

Part of the Political Science Commons

Hibbing, John R. and Crook, Sara Brandes, "A Not-so-distant Mirror: the 17th Amendment and Congressional Change" (1997). Faculty Publications: Political Science. 13.

https://digitalcommons.unl.edu/poliscifacpub/13

This Article is brought to you for free and open access by the Political Science, Department of at DigitalCommons@University of Nebraska - Lincoln. It has been accepted for inclusion in Faculty Publications: Political Science by an authorized administrator of DigitalCommons@University of Nebraska - Lincoln. 


\title{
A Not-so-distant Mirror: the 17th Amendment and Congressional Change SARA BRANDES CROOK Peru State College JOHN R. HIBBING University of Nebraska-Lincoln
}

\begin{abstract}
1 the beginning of the century, the Constitution was amended to permit direct election of U.S. senators. We examine the shift to determine the extent to which an electoral reform can result in meaningful change. Variables are analyzed that tap the Senate's membership and responsiveness before and after direct election, and House data are employed to control for history effects. The results indicate that changing the mode of senatorial selection did indeed lead to alterations in the composition and sensitivity of the Senate, a finding that should encourage caution regarding the electoral reforms being advocated at the end of the century.
\end{abstract}

$\mathbf{T}$ he selection of U.S. senators by state legislators occurred for the last time in November 1912. Just a few months later, on May 31, 1913, the 17 th Amendment to the U.S. Constitution went into effect. It brought down the curtain on indirect elections by altering Article 1, Section 3, such that subsequent Senate vacancies were filled via direct popular elections. Indirect senatorial elections had always been controversial. At the Constitutional Convention the procedure eventually passed 10-0 (Madison [1840] 1987, 87), but Alexander Hamilton, Elbridge Gerry, James Madison, and especially James Wilson all expressed reservations. Wilson's advocacy of direct elections was taken up by others over the decades and began to gain great momentum in the late 1880 s (see Swift 1996, 176). In the first session of the 52d Congress (1891) alone, the House received seven memorials from state legislatures, 54 petitions from interest groups, and 25 proposed resolutions from members of Congress advocating direct popular election of senators (Riker 1955, 467). In fact, in each session of Congress between 1893 and 1911, the House passed a popular election amendment only to see it fail in the other chamber, where sitting senators had a vested interest in preserving a method of selection that had been good to them (Perrin 1910).

Impatience with this situation led a number of states, beginning in 1904, to adopt the "Oregon model," which extracted pledges from state legislators that they would honor the outcome of popular referenda on the Senate contests in their state. Passage of the constitutional amendment should thus be seen as the culmination of a movement that brought about what Senator Robert Byrd (D-WV) believes to be "the single most impor-

Sara Brandes Crook is Assistant Professor of Social Science, Peru State College, Peru, NE 68421. John R. Hibbing is Professor of Political Science, University of Nebraska-Lincoln, Lincoln, NE 68588.

Some of the data used were originally collected by Carroll $R$. McKibbin, maintained by the Inter-university Consortium for Political and Social Research (ICPSR 7803), and cleaned under a National Science Foundation grant to John R. Hibbing as part of the Collaborative Research on a Relational Database on Historical Congressional Statistics, 1788-1992 (SES-9318536), Elaine Swift, project coordinator. Hibbing received additional financial support from the University of Nebraska Foundation Congress Fund. The authors gratefully acknowledge the assistance of John Alford, Ronald F. King, Elaine Swift, and Eric Tiritilli, tant reform of the Senate" (1988, 387). Alan Grimes goes farther: "No amendment has so fundamentally altered the design of the original structure of government" $(1978,2)$. Not surprisingly, observers expected this reform to have momentous consequences. Prior to enactment, both supporters and opponents were issuing incautious predictions. Perhaps the most egregious came on the Senate floor itself, where Senator George $\mathrm{F}$. Hoar (R-MA) intoned: "Let no man deceive himself into the belief that if this change be made, the Senate of the United States will long endure" (Congressional Record 106 [1893]). Others, such as Senator Porter McCumber (R-ND), claimed direct election would result in the complete elimination of political parties (Congressional Record 47 [1911]). Proponents were equally hyperbolic. They believed direct election would eradicate political graft, bribery, and corruption, thereby revitalizing the entire political system by shifting power from parties and state legislatures to "uncorrupted" lay voters (Daynes 1971, 15-6; Lowry 1911; Mitchell 1896). As George Haynes (1938, 1005) later noted, "the champions of the change predicted that it would effect revolutionary reform in the personnel of the Senate."

Somewhat surprisingly, systematic analyses of the actual as opposed to expected consequence of direct elections are not plentiful. King and Ellis $(1996,72)$ observe that, "oddly, there have been few academic studies of this amendment, and fewer still that have employed the theoretical insights and methodological sophistication of modern social science" (but see Crook 1992, Daynes 1971, Ellis and King 1996). To the extent an opinion has been formed, it seems to be that the consequences were minimal. Haynes, once a leading advocate (1906), was disappointed with the reality of direct elections, writing that no large effect was evident $(1938,1005)$. Bickel $(1968,3)$ sees the institution of direct senatorial elections as perhaps the quintessential example of the "illusion-disillusion" pattern of democratic reform. Daynes agrees $(1971, \mathrm{vi})$, and he concludes that expectations were "exaggerated and overstated" (1971, 149). But for the most part such conclusions are derived from impressionistic rather than systematic analyses. We believe a more concerted investigation is merited.

Much can be learned from determining the extent to which changing the method of senatorial selection 
altered the Senate itself. The objectives of reform were unusually clear and afford us the opportunity to ascertain whether they were accomplished. Are Bickel and others correct to be cynical about the prospects for democratic reform, or is their conclusion attributable to inadequate research designs? This question is particularly poignant in light of the resurgent interest in democratic reform. Just as the 20 th century began with substantial interest in populist electoral reform, so is it ending. Limiting the number of legislative terms is now the reform of choice, favored by approximately threefourths of the American population. As was the case with direct election of senators, the target is a congressional membership thought to be under the thumb of special interests and, therefore, out of touch with ordinary Americans. Many believe that changing the nature of elections will restore to the people their rightful role in legislative government. The parallels between the direct election and term limit movements, right down to the efforts of each to proceed without a constitutional amendment although one would seem to be required, are at times uncanny. The Oregon model of listing on the ballot the candidates pledged to vote in accord with the people's senatorial preferences has merely been replaced by the U.S. Term Limits model, which lists on the ballot whether a congressional candidate is pledged to support term limits. As such, using the direct election movement as a mirror may provide information on the potential effect of current electoral reform proposals.

Our primary purpose is to present systematic evidence on the degree to which the 17th Amendment had any consequences. It is impossible to test each and every alleged consequence, so we concentrate on a manageable number of what seem to be the more central and likely effects. These primarily relate to Senate composition and responsiveness. This is appropriate, since changes in the membership and "connectedness" of the Senate were the main desires of reformers.

\section{CHANGES IN MEMBERSHIP TRAITS}

We begin with the membership of the Senate. Unlike most institutions, democratic legislatures are often evaluated by membership traits. After all, as Hanna Pitkin (1967) and others have so ably argued, descriptive as well as substantive representation is important. To many people, it is essential that a legislative body look a certain way, not just act a certain way; besides, it is commonly felt that the former affects the latter.

Such was the thinking, at least, among those who argued for changing the mechanism by which senators are chosen. Supporters of direct elections were convinced that reform would alter the kind of person typically serving in the Senate, and they wanted desperately to accomplish this goal. Reformers felt that senators were aristocratic and detached from ordinary people, that they came from aloof and monied families, and that they eamed their Senate positions not because of demonstrated expertise in affairs of government but because of family connections (Agar 1950, 575-82; Phillips 1906; Rothman 1966, 250).

Of course, where proponents of reform saw the need to populate the Senate with ordinary people of the state, defenders of the status quo feared that direct election would open the doors to "a crowd of incompetent, unfit, rash, socialistic and radical men who have no proper views of government" (exchange between Heybum [R-ID] and Cummins [R-IA] on the Senate floor, Congressional Record 47 [1911]). But whether a more popularly oriented body was viewed as improving or harming the polity, the point is that both sides expected the switch to have a significant effect on the composition of the Senate. Is there evidence to support this belief?

It is difficult to acquire objective data on the degree to which a senator is aristocratic and under the thumb of large monied interests, such as the railroads, or is a reasonably typical citizen of the relevant state. We employ two measures that are suggestive but not definitive. The first is whether a senator's family was a wealthy political dynasty. The second is the extent to which a senator had previous experience in government.

\section{POLITICAL DYNASTIES}

Critics of indirect election believed the process afforded special advantages to the well-connected and the well-heeled. It was argued that direct election would demonstrate that ordinary people were not so impressed with family dynasties and the trappings of wealth. One partial test of this expectation is whether a senator had a relative who previously served in Congress. The hypothesis is that direct election will diminish the percentage of senators from politically influential families. Individual-level information on senators with such relatives was aggregated for each Congress so that changes over time could be analyzed.

A danger in this type of analysis is that any change observed may be attributed to the advent of direct election but may be due to broader historical forces. On this count, bicameralism proves to be analytically useful. The enactment of direct election to the Senate should be largely irrelevant to the composition of the House of Representatives. We have data on the percentage of House members from politically influential families. Support for our hypothesis will be heightened if a similar degree of decrease did not occur in the House, where election mechanisms were not altered.

In Figure 1, we juxtapose the trend in the Senate (Panel A) and in the House (Panel B) for the 12 congresses before and the 12 congresses after full implementation of the 17th Amendment. As might be expected, representatives were much less likely than senators to have relatives who previously served in Congress. For the 24 congresses (54th through 77th, 1895-1942) in question, both chambers experienced a decrease, but it appears more pronounced in the Senate after direct election than might have been expected had pre-1918 trends continued. During the first six congresses after the 17th Amendment became applicable to all Senate terms (i.e., beginning in 1918), 


\section{FIGURE 1. Percentage of Members with Relatives in Previous Congresses}

\section{Panel $A$ \\ Senate Data}

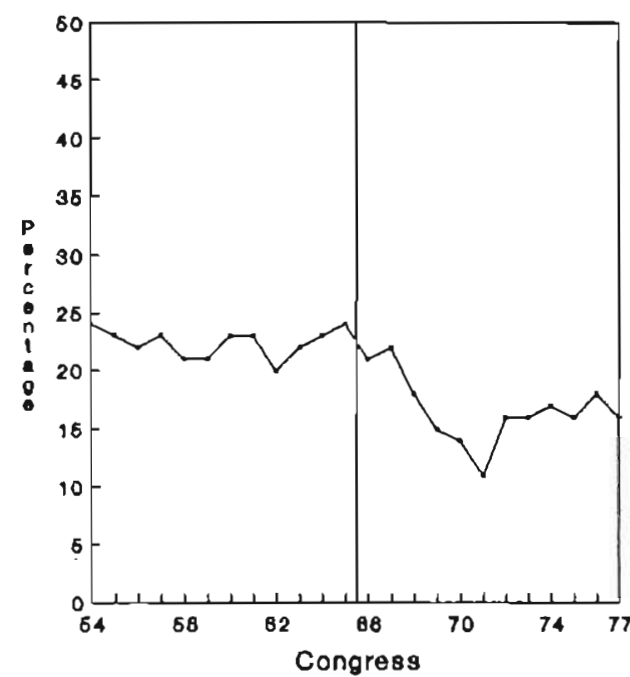

Panel C

Senate Trend Lines

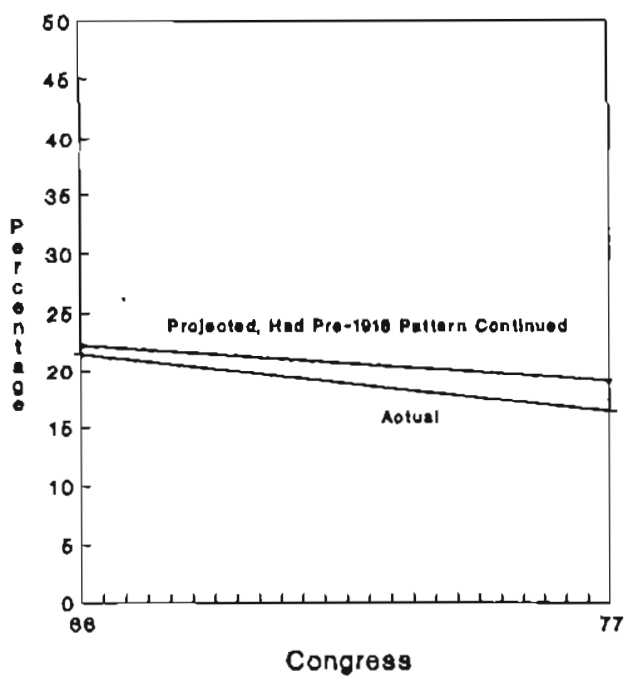

Panel B

House Data

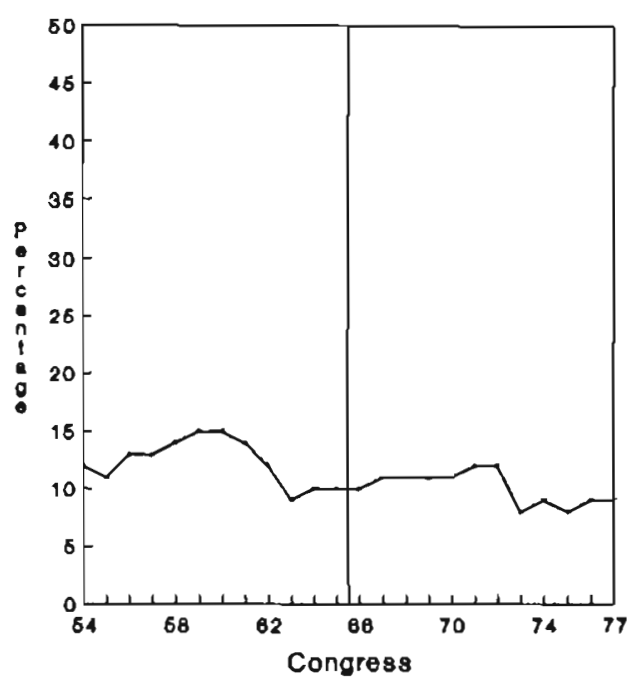

Panel D House Trend Lines

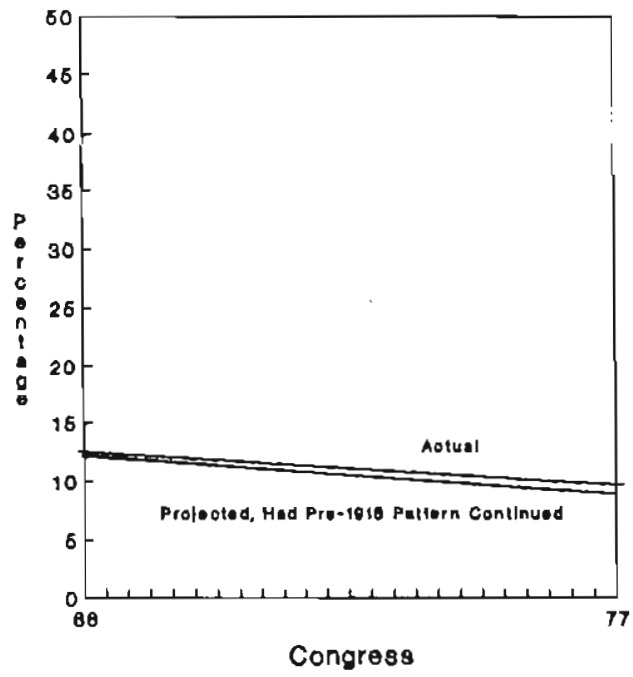

Source: Cleaned version of ICPSR 7803, Blographical Directory of the U.S. Congress, 1789-1989. See unnumbered note on page 845. Note: In Panel C the "actual" line represents the pattern produced by direct election whlle the "projected" line ls an estlmate of the likely pattern had indirect election continued. The vertical line in panels A and B represents the advent of universal direct election In the Senate.

a marked downward trend is noticeable in the Senate; then it levels off, and there is even a mild reversal. On the House side, if anything, the decline slows after 1918 , but there certainly is no sharp drop.

We regressed the Senate "political dynasty" variable on a simple counter variable (ranging from 1 in the 54th Congress to 24 in the 77 th), on a dummy variable ( 0 for before and 1 for after 1918), and on an interac- tive variable (dummy*counter) in standard form (see Gujarati 1995, 512-4). This formulation is graphed in Panel $\mathrm{C}$ and indicates whether the intervention (in this case, full implementation of the 17th Amendment) precipitated a change in intercept (captured by the dummy) and/or a change in slope (captured by the interactive term). Even though the House did not experience change in its basic electoral structure, par- 
allel procedures were employed for the House data (see Panel D) to determine whether larger historical trends could be responsible for changes in the Senate.

Theory leads us to anticipate that the expected decrease in the percentage who come from connected families will not occur all at once but over time, as voters become accustomed to direct election and as prospective candidates determine the type of individual preferred by the people. Thus, we expect a (negative) change in slope in the Senate (and not in the House) more than any change in intercept. OLS estimates indicated autocorrelation, so the coefficients presented below were obtained using Cochrane-Orcutt correction procedures (SHAZAM, Version 7.0).

$$
\begin{aligned}
& Y_{S F}=25.41+1.26(D)-.26(C)-.17\left(D^{*} C\right)+e \text {, } \\
& \begin{array}{llll}
(2.41) & (2.22) \quad(.22) \quad(.12)
\end{array} \\
& \text { Adj. } R^{2}=.73, N=24 \text {, } \\
& Y_{H F}=15.38+.04(D)-.27(C)+.03\left(D^{*} C\right)+e, \\
& \begin{array}{llll}
(1.66) \quad(1.53) \quad(.15) \quad(.40)
\end{array} \\
& \text { Adj. } R^{2}=.58, N=24 \text {, } \\
& \text { rho }=.52 \text { (reached equilibrium in four iterations), } \\
& Y_{S F}=\% \text { of senators with relatives who served in } \\
& Y_{H F}=\% \text { of representatives with relatives who } \\
& D=\text { dummy }(0,54 \text { th }-65 \text { th congresses; } 1,66 \text { th- } \\
& C=\text { counter }(1-24 \text { congresses }) \text {, } \\
& e=\text { error term, and } \\
& \text { ( ) = standard error. }
\end{aligned}
$$

The results are somewhat consistent with expectations. In panels A and B of Figure 1 it appears as though the movement away from having relatives who served in Congress is more pronounced in the Senate and after direct elections. Fitting regression lines to the data points supports this perception. The "counter" trends (representing the pre-1918 pattern) are virtually identical in the Senate and House, but the coefficients for the interactive term (representing the change in slope occurring around 1918) are quite different. The House trend actually flattens out slightly, and the Senate trend declines more sharply than ever. This is seen graphically in panels $C$ and D of Figure 1, where estimates based on the patterns before and after the advent of direct elections in the Senate are presented for each chamber). No doubt the Senate interactive coefficient would have been even more strongly negative but for the slight upturn in the dependent variable in the later years of the time series. The only real disappointment is that the coefficient for the interactive term in the Senate fails to meet standard tests of statistical significance-but just barely. Of course, interactive terms tend to be highly colinear with their parent variables. While not biasing the coefficients themselves, multicolinearity does inflate the standard errors, meaning variables may look statistically insignificant when in actuality they are significant.

It appears that direct election helped reduce the number of senators coming from a political dynasty. Did it also decrease the number coming from wealthy families? Not all politically connected families are necessarily wealthy, so brief attention to this trait is appropriate, particularly since a major goal of reformers was to disconnect the Senate from engines of wealth. As Haynes $(1906,173)$ states: "It is to be expected that under popular election there would be sent to the Senate fewer merely rich men-men whose entire past has been devoted to wealth-getting or wealth spending, and who have given no hint of any aspirations or aptitudes for statesmanship." Did direct elections have the intended effect?

The data are not available to answer this question systematically. Neither income tax returns nor financial disclosure requirements existed before the 17th Amendment was enacted. There is impressionistic evidence, however, of changes in the wealth contours of the Senate. Shortly after the turn of the century, 23 of the 90 senators were acknowledged to be "citizens of great wealth" (Financial Red Book of America 1903; World Aimanac 1902). We followed the elections to these 23 seats to see whether they continued to be filled by people of great wealth.

Five of the 23 indirectly elected wealthy senators survived the first direct election in their state: Henry Cabot Lodge (R-MA), Thomas S. Martin (D-VA), Francis G. Newlands (D-NV), Reed Smoot (R-UT), and Francis E. Warren (R-WY); a sixth, Stephen B. Elkins (R-WV), was replaced by his son Davis. No movement toward people of ordinary means occurred in these cases. The history of the 17 other seats, however, suggests a modest push toward a less wealthy Senate. Judging from the Biographical Directory of the American Congress, 1789-1989, as well as newspaper accounts, nine of the wealthy senators were replaced by wealthy men.'

In other words, of the 23 Senate seats held by truly wealthy individuals before direct election, 15 were held by wealthy senators after the shift. Whether this is a victory for reformers is open to question. Clearly, the 17th Amendment did not render it impossible for the well-to-do to secure membership in the Senate (see also Hoebeke 1995, 190). Indeed, wealthy senators are much in evidence today and are not in any way incompatible with popular elections. Yet, rough estimates suggest that the immediate effect of the change was to drop the ratio of wealthy senators from about one in four to one in six, and perhaps a shift of this magnitude was as much as the reformers could expect.

\footnotetext{
1 Though the method is unscientific, it is actually fairly easy to identify senators of wealth by perusing these sources. Entries that mention private tutors; preparatory schools; European travel; "interests" in timber, mining, transportation, banking, real estate, and so forth; the presidency or chairmanship of furms; service on boards of directors; and the like are in contrast to entries noting public schools, involvement with manual trades, school teaching, street-level journalism, or general law practice.
} 


\section{GOVERNMENT EXPERIENCE}

Just as elections by ordinary people are likely to decrease the number of senators from wealthy and/or politically infuential families, it can be hypothesized that they are likely to increase the number with government experience. The rationale is that a solid record of government service will attract voters (more than it attracted state legislators) and eventually become a more common trait of elected senators.

The procedures used to test this expectation paralle! those described with regard to political dynasty (Figure 1 ). The only difference is that in this case the dependent variable measures a senator's previous government experience. ${ }^{2}$ The results are presented in Figure 2 and in the following equations.

$$
\begin{aligned}
& Y_{S G}=1.32-.39(D)-.015(C)+.03\left(D^{*} C\right)+e, \\
& \text { Adj. } R^{2}=.71, N=24 \text {, } \\
& \text { rho }=.37 \text { (reached equilibrium in six iterations); } \\
& Y_{H G}=1.10+.29(D)+.007(C)-.02\left(D^{*} C\right)+e, \\
& \begin{array}{llll}
(.01) & (.03) \quad(.001) \quad(.002)
\end{array} \\
& \text { Adj. } R^{2}=.80, N=24 \text {, rho }=.00 \text {, }
\end{aligned}
$$

Previous government experience was trending downward for the Senate very early in the century, but the pattern reversed dramatically in the 1920 s. The extent to which direct elections are responsible is open to question. The case would be stronger if the increase had commenced closer to full implementation in 1918 (see also Daynes 1971, 100). Still, members of the House certainly were not pushed in the same direction. In Panel B and of Figure 2 we see their levels of previous experience declining around this time. If government service had become more pertinent to Senate races, then perhaps experienced candidates were drawn to those rather than House contests. The regression lines, corrected for autocorrelation, reveal significant and fairly dramatic differences between the two bodies. Direct election may have increased the degree to which senators had previous government experience, but in the House, the opposite occurred.

\footnotetext{
2 Members with no previous govemment service were coded 0 ; those with experience at the local level only were coded 1 ; those with state-level experience were coded 2; and those with federal-level experience were coded 3. The Biographical Directory of the American Congress, 1789-1989, records no information on the length of time spent in each previous position.
}

The results are consistent with these interpretations, but there is no way conclusively to tie changes to the 17 th Amendment.

\section{CHANGES IN LEVEL OF RESPONSIVENESS}

Membership composition was not all that reformers hoped to change through direct election. Many observers believed that senators would become more responsive to changes in public sentiment. John $\mathrm{H}$. Mitchell $(1896,395)$ noted "a belief in the public mind that proper deference is not given by the Senate to the demands and interests of the people." He went on to remark that elections by the people rather than the legislatures would quite likely solve the problem. Making the Senate more sensitive to fluctuations in the public mood was a common goal of reformers, and in this section we determine whether that was accomplished.

Greater sensitivity could not be secured if the membership remained unchanged, so the first question is whether direct election stimulated legislative turnover. In the short run, it certainly did. If the focus of attention is strictly on the amount of turnover caused immediately by the transition, then there is little doubt that many Senate careers were disrupted. We determined the date of the initial direct election in all 48 U.S. states. This ranged from 1908 (for Oregon's Class 3 elections) to 1918 (for states having Class 2 elections and not adopting direct election prior to the 17th Amendment). We then determined the amount of turnover at this intersection of indirect and direct election, uneven as it was across the country.

Out of 96 cases occurring in these first direct elections from 1908 to 1918, the previous incumbent survived in 54 direct elections (56\%). Of the remainder, 13 incumbents ran and lost in the general election, 8 ran and lost in the primary, and 14 chose not to run; 7 seats involved vacancies. ${ }^{3}$ In other words, the first direct election produced 42 winners $(44 \%$ ) who had not been senators the previous term. To provide some sense of perspective, the mean percent of new members in the six actual Senate election years from 1908 to 1918 inclusive was 21.5 , substantially and significantly below the 44 percent mentioned above. Clearly, a large portion of the indirectly elected Senate was not prepared to cope with direct election. ${ }^{4}$

\footnotetext{
${ }^{3}$ Several of these involved short-term appointees who could be viewed as incumbents and could have run for the ensuing full term. Therefore, the number choosing not to run may exceed 14 .

4 It should be noted, however, that after this initial turnover the long-term effect of direct election may have been to increase career length. It is difficult to make confident statements about cause and effect, since congressional stays were lengthening generally during this period, but the results suggest a more dramatic increase in the Senate than in the House. Just as voters apparently were more eager than state legislators to have senators with previous government experience (see Figure 2), they also seemed slightly more attracted to candidates with congressional service (a sentiment not in evidence among modern voters).
} 


\section{FIGURE 2. Mean Level of Pre-Congress Government Service}

\section{Panel A \\ Senate Data}

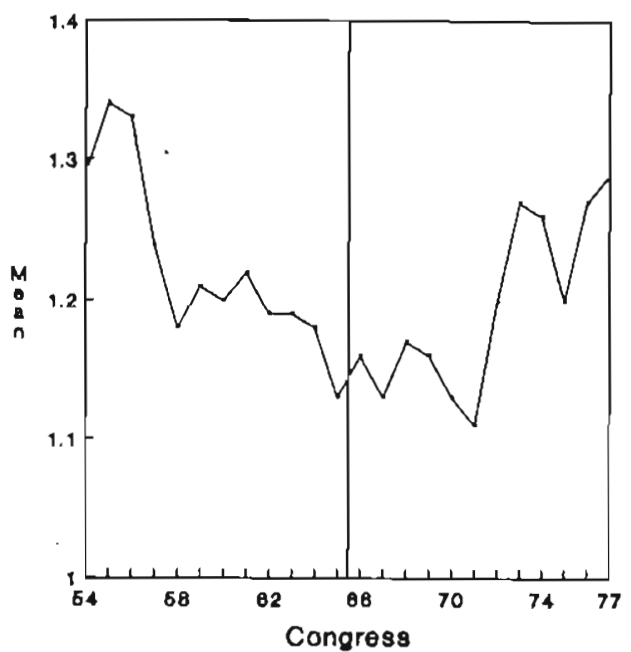

Panel C Senate Trend Lines

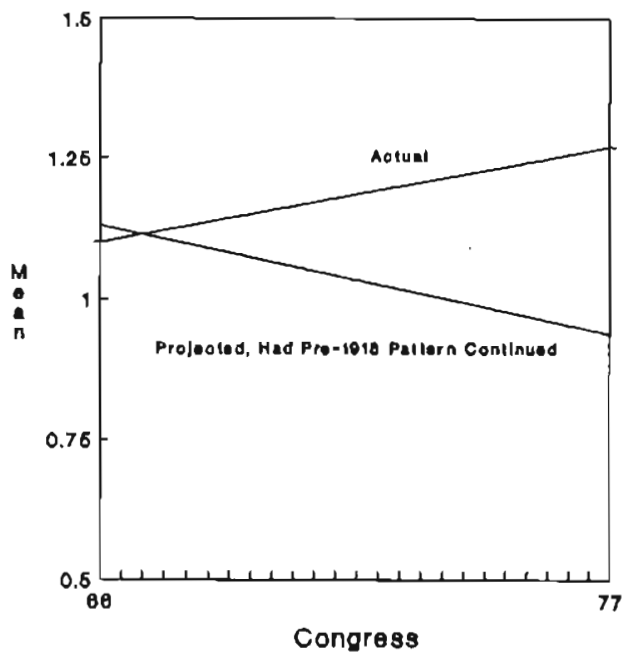

Panel B House Data

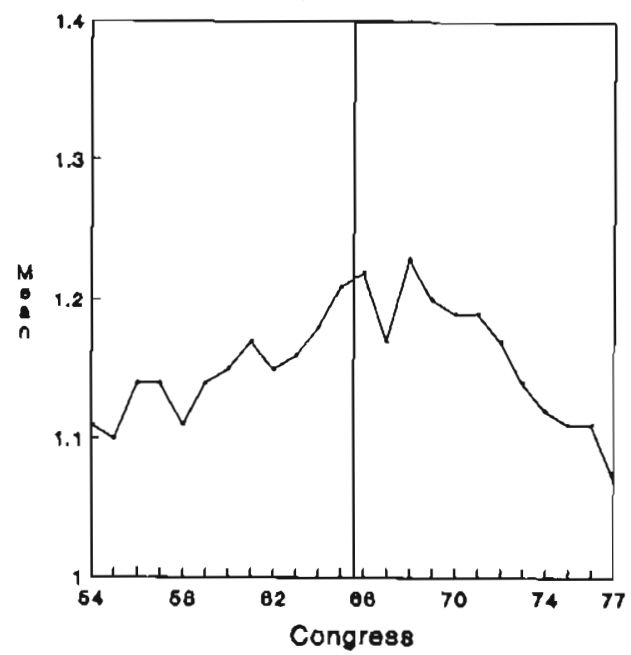

Panel D House Trend Lines

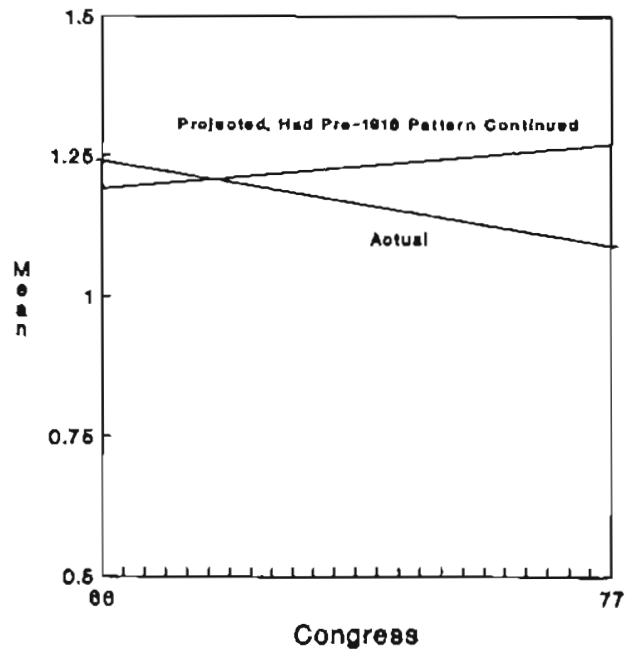

Source: Cleaned version of ICPSR 7803, Blographical Dinectory of the U.S. Congress, 1789-1989. See unnumbered note on page 845. Note: In Panel C the "actual" Ine represents the pattern produced by direct election whlle the "projected" Ine is an estlmate of the llkely pattern had indirect election continued. The vertical line in Panels $A$ and $B$ represents the advent of universal direct election in the Senate.

\section{RAPIDITY OF PARTISAN CHANGE}

A better way to evaluate responsiveness is the speed with which partisan change occurred in the Senate. The logic of the founders was that the Senate as a body would be slower to move than the House. In this manner, the Senate would "protect the people against the transient impressions into which they themselves might be led"
(Madison [1840] 1987, 193). With indirect election, plus lengthy and staggered terms, senators would be less susceptible to popular whims. Current passions would be more directly and immediately reflected in the composition of the House, but the Senate would afford officials the opportunity to reflect upon whether or not these passions were more than passing fancies. 
The original constitutional design envisioned that a change of majority party in the House would be followed (if the "new" direction were deemed widely desirable) by a similar change in the Senate or (if undesirable) by a reversion of the House to the previous majority party while the Senate impassively watched the stops and starts of the House. Since the 17th Amendment removed a key factor insulating the Senate from "whims," we hypothesize that its enactment should alter the patterns anticipated by the founders. That is, with both bodies being popularly elected, partisan change is more likely to be simultaneous rather than lagged (or nonexistent in the Senate).

If we examine the 50 years both before and after enactment of the 17th Amendment, then we find an instructive contrast. From 1862 to 1912, there are five instances of the constitutionally anticipated pattern. In four cases a party switch in the House was parroted two years later in the Senate (Republican to Democrat in the 1876 House and 1878 Senate; Democrat to Republican in the 1880 House and 1882 Senate; Republican to Democrat in the 1890 House and 1892 Senate; and Republican to Democrat in the 1910 House and 1912 Senate). In one case the House switched twice-from Republican to Democrat (1882) and back again (1888) before the Senate moved at all. Remarkably, during this entire period, only once did a party switch not follow the foreseen sequence: In 1894 the House and Senate simultaneously changed from a Democratic to a Republican majority.

During the 50 years after 1913, the case record is just the opposite: one in the anticipated pattern and five exceptions to it. The House switched to a Democratic majority in 1930, two years before the Roosevelt realignment, but the Senate did not follow suit until FDR's election in 1932, thus reproducing the pattern of cautious Senate movement intended by the founders. But, outside of this series of events, no other instance of party switching subsequent to enactment of the 17th Amendment has given any indication of the Senate being more "cautious." In 1918, 1946, and 1952, both chambers simultaneously switched from a Democratic to a Republican majority, and in 1948 and 1954 both did the reverse.

Before 1913 the Senate usually fulfilled its intended role of lagging behind or standing pat, but after 1913 it almost always moved in lockstep with the House. In the 1980s there was even the unprecedented phenomenon of the Senate moving and the House standing pat. For better or worse, the Senate lost an important insulating agent-indirect elections. Causation cannot be proved, but it appears the 17th Amendment played a role in making the Senate a more rapidly responding institution (see also Alford and Hibbing 1989).

\section{RESPONSIVENESS TO PUBLIC SENTIMENT}

Another approach is to determine whether a change in the share of partisan seats (not necessarily entailing a switch in majority) is closely tied to changes in the voting behavior of the people. This information is difficult to obtain for periods predating modern survey techniques. Still, with a few assumptions it is possible to approximate a test of the hypothesis that the Senate became more responsive to public opinion after the advent of direct election.

The most important assumption we make is that a shift in the popular vote for president reflects a shift in general partisan preferences. While that assumption is not without problems, it is more accurate for the earlier part of this century than today. At issue is whether shifting partisan preferences in presidential races are reflected in the partisan distribution of Senate seats. We hypothesize that direct election will produce a tighter match between these shifts. In other words, shifts in presidential voting will not do a good job of predicting shifts in the Senate before the 17th Amendment but will do a better job afterward. This is based on the notion that state legislators were not particularly sensitive to public sentiments when they selected senators.

To test this hypothesis, we recorded shifts in the partisan distribution of both presidential voting and seats in the Senate and the House. For example, between 1860 and 1864, the two-party vote for the Republican candidate for president (Abraham Lincoln) declined by $2.4 \%$. At the same time, the share of Republican seats increased by $5.2 \%$ in the Senate and by $7.1 \%$ in the House.

Since only one data point is available every four years, we extended the period analyzed beyond that used in some portions of this study. We cover 1860 to 1964 but exclude 1908-16, both because the transition to direct election occurred then and because 1912 was an extremely unusual presidential election. It is the only presidential election since the Republican Party was formed in which the Democratic and Republican nominees did not finish 1-2 in the presidential contest. Even though we use percentage of the two-party vote in the analysis, the disruption owing to Theodore Roosevelt's third-party candidacy is unprecedented and misleading (suggesting more Democratic strength than actually existed). These exclusions create two separate data sets; one running from 1860 to 1908 and the other from 1916 through 1964.

While conceptually cleaner, blocking out the transitional years makes it inappropriate to treat the data in a single equation fashion as was done in conjunction with figures 1 and 2.5 Treating the data as two separate time series, in turn, results in a loss of degrees of freedom and makes it impossible to offer firm statements about the significant levels of difference in equation parameters. But this procedure should be sufficient to give at least an indication of whether the connection between partisan shifts in presidential preference and Senate seats became tighter as a result of the 17th Amendment.

Once again, the House is used as a control for historical changes that may come into play. Our hy-

\footnotetext{
5 Viewing the dummy as reflecting the new intercept, for example, is not entirely accurate, since a significant gap exists in the time series. Equal spacing of data points is necessary in continuous time series.
} 
TABLE 1. Responsiveness of House and Senate to Partisan Shifts in Presidential Election: Before and After Direct Election in the Senate

\begin{tabular}{|c|c|c|c|c|}
\hline & \multicolumn{2}{|c|}{$\begin{array}{c}\% \text { Change in Republican Senate } \\
\text { Seats, } t-4 \text { to } t\end{array}$} & \multicolumn{2}{|c|}{$\begin{array}{l}\% \text { Change in Republican House } \\
\text { Seats, } t-4 \text { to } t\end{array}$} \\
\hline & Before 1912 & After 1912 & Before 1912 & After 1912 \\
\hline $\begin{array}{l}\text { Constant } \\
\text { (s.e.) }\end{array}$ & $\begin{array}{l}-.65 \\
(2.46)\end{array}$ & $\begin{array}{l}-.23 \\
(2.24)\end{array}$ & $\begin{array}{r}.51 \\
(3.17\end{array}$ & $\begin{array}{l}-.46 \\
(2.48)\end{array}$ \\
\hline$b$ & .75 & $1.09^{*}$ & $1.93^{*}$ & $1.33^{*}$ \\
\hline (s.e.) & $(.65)$ & $(.26)$ & $(.84)$ & (.28) \\
\hline Adj. $R^{2}$ & .03 & 61 & .29 & .66 \\
\hline$F$ & 1.31 & $17.99^{*}$ & $5.30^{*}$ & $22.10^{*}$ \\
\hline D.W. & 1.52 & 2.01 & 2.71 & 2.82 \\
\hline$N$ & 12 & 12 & 12 & 12 \\
\hline
\end{tabular}

pothesis is that presidential election shifts will be more relevant to the partisan composition of the Senate after direct election was instituted, so we expect the post1912 equations in the two chambers to be more similar to each other than are the pre-1912 equations. The best way to present the results is a series of four simple regression equations (Senate before; Senate after; House before; House after), as shown in Table 1.

As expected, the post-1912 equation in the Senate is much stronger than the pre-1912 equation. A shift of $1 \%$ in presidential vote toward the Republicans yields an increase of more than $1 \%$ in the Republican share of Senate seats compared to the previous election, a substantially larger shift than is predicted during the pre-1912 period (.75). Even at that, the pre-1912 coefficient fails to achieve statistical significance. More important, the presidential shifts do a much more accurate job of predicting shifts in the partisan composition of the Senate after 1912. Presidential election shifts explain only $3 \%$ of the variance in Senate shifts, prior to the 17 th Amendment, but afterward they account for $61 \%$ of the variance; the $F$-statistic is significant after and not before.

But perhaps presidential elections simply became more relevant to congressional politics as the century progressed. If so, then we should find a pattern of results in the House similar to that in the Senate. The last two equations of Table 1 indicate that this is not entirely the case. As expected, presidential elections are much more predictive of House than of Senate composition in the earlier period. Later, despite becoming somewhat more determinative of House composition (although the size of the regression coefficient is actually reduced by nearly one-third, from 1.93 to 1.33), presidential elections are no more able to predict House shifts than Senate shifts.

The most important conclusion from this portion of the analysis is that Senate elections once were nearly completely detached from presidential politics. With the advent of the 17th Amendment, the contours of the Senate came to be shaped by shifts in partisan performance in presidential races in the same manner as the House (compare the $R^{2}$ for the post-1912 House and Senate). This has had lasting consequences, and in fact discussion has intensified in recent decades over the hypersensitivity of the Senate. ${ }^{6}$ No doubt much of this was bound to happen anyway, but the change to direct election certainly is implicated in the Senate's abrogation of its duty to be the "saucer that cools the coffee" (see Fenno 1982, 5).?

\section{CONCLUSION}

Woodrow Wilson $(1885,3)$ noted that "the Senate is just what the mode of its election and the conditions of public life in this country make it." If Wilson's contention is accurate, then a change in the mode of election should produce changes in the Senate (holding constant the "conditions of public life"). This study provides evidence that a shift in the mode of election did lead to changes in the Senate. Clearly observable consequences flowed from the 17th Amendment. These can be seen in the kinds of people who became senators as well as in the degree to which the Senate is responsive to the public mood. It is also likely that, as a result of the shift to direct election, both the Senate and the state legislatures experienced change in structure, procedures, and institutional position, although at this point we lack the data to offer detailed evidence of these purely procedural/institutional changes.

The findings we do present support the conclusion that the shift from indirect to direct election had implications for many facets of the Senate. Traits of typical senators changed in such a way as to suggest that, relative to the preferences of state legislators, ordinary people desired someone with government experience rather than wealth and family connections. Change also appeared in the manner the Senate responded to fluctuations in public sentiment. Specifically, it reacted to the popular mood with more sensitivity and more rapidity. For better or for worse, direct election rendered the Senate less sedate and more closely tied to the people, synchronizing it with the

\footnotetext{
6 Alan Ehrenhalt $(1986,583)$, for example, notes that "the modern Senate does not cool any passions. If anything, it heats them up... The Senate has all the political hypersensitivity of the House if not more."

"For evidence on changes in the degree to which the Senate is responsive to state legislative partisan composition, see King and Ellis 1996. On changes in the swing ratio, see Stewart 1992.
} 
House and the presidency; in fact, it often looks much like a smaller version of the House.

The populist reform agenda has popular support as enthusiastic today as it was 100 years ago during the buildup to the 17th Amendment. Ballot reforms and senatorial direct election have been replaced in the public eye with initiative votes and legislative term limits, but the impulse to empower the people at the expense of the elite (whether the elite are believed to be monied interests, as before, or "special" interests, as now) is consistently strong. Contrary to those who believe reforms are destined to failure and are unlikely to produce any significant change (see Bickel 1968, 3; Daynes 1971, vi; Haymes 1938, 1005), our results suggest that proposed changes should not be taken lightly. Arguments will continue as to whether the 17th Amendment had good or bad consequences, but it is abundantly clear that changes did occur as a result of direct election. Institutions like the Senate may not be total creatures of their "mode of election," but they are at least partially shaped by it. In one sense, it is encouraging that political institutions are not carved in stone, but the very malleability we have underscored makes it essential for the public to consider carefully the reforms for which it agitates.

\section{REFERENCES}

Agar, Herbert. 1950. The Price of Union. Boston: Houghton Mifflin. Alford, John R, and John R. Hibbing. 1989. "Electoral Sensitivity in the United States Congress." Presented at the annual meeting of the Western Political Science Association, Salt Lake City, UT, March-April.

Bickel, Alexander M. 1968. The Age of Political Reform. New York: Harper and Row.

Biographical Directory of the American Congress, 1789-1989, Bicentennial Edition. 1989. Washington, DC: U.S. Govermment Printing Office.

Byrd, Robert C. 1988. The Senate 1789-1987: Addresses on the History of the United States Senate. Washington, DC: U.S. Government Printing Office.

Congressional Record. Various editions. Washington, DC: U.S. Government Printing Office.

Crook, Sara Brandes. 1992. "The Consequences of the Seventeenth Amendment: The Twentieth Century Senate." Ph.D. diss., University of Nebraska.
Daynes, Byron W. 1971. "The Impact of the Direct Election of Senators on the Political System." Ph.D. diss., University of Chicago.

Ehrenhalt, Alan. 1986. "The Senate: World's Least Effective Saucer." Congressional Quarterly Weekly Report 44(8 March):583.

Ellis, Susan, and Ronald F. King. 1996. "Rules and Results: The Impact of the 17th Amendment on the Composition of the U.S. Senate." University of Michigan. Typescript.

Fenno, Richard F., Jr. 1982. The United States Senate: A Bicameral Perspective. Washington, DC: American Enterprise Institute.

Financial Red Book of America. 1903. New York: Financial Directory Association.

Grimes, Alan P. 1978. Democracy and the Amendments to the Constitution. Lexington, MA: Lexington Books.

Gujarati, Damodar N. 1995. Basic Econometrics, 3d ed. New York: McGraw Hill.

Haynes, George H. 1906. The Election of Senators. New York: Henry Holt.

Haynes, George H. [1960] 1938. The Senate of the United States. New York: Russell and Russell.

Hoebeke, C. H. 1995. The Road to Mass Democracy: Original Intent and the Seventeenth Amendment. New Brunswick, NJ: Transaction Publishers.

King, Ronald F., and Susan Ellis. 1996. "Partisan Advantage and Constitutional Change: The Case of the 17th Amendment." Studies in American Political Development 10(Spring):69-102.

Lowry, E. G. 1911. "Senators by Direct Vote." Harper's Weekly (18 February): 10

Madison, James. [1840] 1987. Notes of Debates in the Federal Convention of 1787. New York: Norton.

Mitchell, John H. 1896. "Election of Senators by Popular Vote." Forum 21:(March-August):392-8.

Perrin, J. W. 1910. "Popular Election of United States Senators." North American Review 192(December):799-804.

Phillips, David Graham. 1906. "The Treason of the Senate." Cosmopolitan, February-April, vanious issues and pages.

Pitkin, Hanna F. 1967. The Concept of Representation. Berkeley: University of California Press.

Riker, William H. 1955. "The Senate and American Federalism." American Political Science Review 49(June):452-69.

Rothman, David J. 1966. Politics and Power: The U.S. Senate, 1869-1901. Cambridge, MA: Harvard University Press.

Stewart, Charles, III. 1992. "Responsiveness in the Upper Chamber: The Constitution and the Institutional Development of the Senate." In The Constitution and American Political Development, ed Peter Nardulli, Urbana: University of Illinois Press.

Swift, Elaine K. 1996. The Making of an American Senate. Ann Arbor: University of Michigan Press.

Wilson, Woodrow. 1885. Congressional Govemment. New York: Houghton Mifflin.

World Almanac. 1902. New York: World Almanac Press. 